\title{
Rancang Sistem Penyajian Bank Soal Untuk Jenjang Sekolah Menengah Atas Berbasis Web
}

\author{
Musriatun Napiah ${ }^{1}$, Mugi Raharjo² ${ }^{2}$ Jordy Lasmana Putra ${ }^{3}$, Sujiliani Heristian $^{4}$,Ilham Nur Leksono \\ 1,4,5 Teknologi komputer; Universitas Bina Sarana Informatika \\ e-mail: ${ }^{1}$ musriatun.mph@bsi.ac.id, ${ }^{4}$ sujiliani.she@bsi.ac.id, ${ }^{5}$ ilham.inl@bsi.ac.id \\ ${ }^{2.3}$ Teknik Informatika; Sekolah Tinggi Manajemen dan Komputer Nusa Mandiri \\ 2mugi.mou@nusamandiri.ac.id, ${ }^{2}$ jordy.jlp@ nusamandiri.ac.id
}

$\begin{array}{ccc}\text { Diterima } & \text { Direvisi } & \text { Disetujui } \\ 23-09-2020 & 09-11-2020 & 01-12-2020\end{array}$

\begin{abstract}
Abstrak - Sekolah Menengah Atas sebagai salah satu institusi penyelenggara pendidikan di Indonesia. Pelaksanaan ujian pada SMA Cengkareng 1 masih bersifat konvensional yang artinya belum adanya metode pembelajaran berbasis web sebagai sarana pendukung dalam pembelajaran di sekolah. Penelitian ini bertujuan untuk merancang aplikasi yang mampu mendokumentasikan seluruh soal dan kegiatan selama pelaksanaan ujian dan pemberian tugas. Analisis dan desain menggunakan metode waterfall. Penelitian diawali dengan proses melakukan studi literature, pengumpulan data, analisis sistem dan kebutuhan, membuat pemodelan sistem menggunakan UML, merancang implementasi aplikasi, melakukan pengujian dengan Black Box Testing dan maintance atau pemeliharaan data sistem. Aplikasi Bank Soal berbasis web dirancang memiliki fitur untuk pendataan soal dan penjadwalannya, monitoring pelaksanaan ujian dan monitoring upload tugas siswa. Hasil penelitian ini dapat digunakan sebagai dasar pengembangan aplikasi Bank Soal berbasis web dalam rangka pengelolaan evaluasi belajar yang lebih interkatif di studi kasus untuk jenjang Sekolah Menengah Atas, sehingga tidak hanya terfokus di pembelajaran di kelas, tetapi siswa juga bisa mengaksesnya via internet di mana saja.
\end{abstract}

Kata Kunci: aplikasi Bank Soal, metode waterfall, siswa

Abstract - High School as one of the educational institutions in Indonesia. Examination at Cengkareng 1 High School is still conventional, which means that there is no web-based learning method as a means of supporting learning in schools. This study aims to design an application that is able to document all questions and activities during the implementation of exams and assignments. Analysis and design using the waterfall method. The research begins with the process of conducting literature studies, collecting data, analyzing systems and requirements, making system modeling using UML, designing application implementations, testing with Black Box Testing and maintaining or maintaining system data. The web-based Question Bank application is designed to have features for data collection and scheduling, monitoring of exam implementation and monitoring student assignments uploads. The results of this study can be used as the basis for developing a web-based Question Bank application in order to manage a more interactive learning evaluation in case studies for high school level, so that it is not only focused on classroom learning, but students can also access it via the internet anywhere.

Keywords: Problem Bank application, waterfall method, students

\section{PENDAHULUAN}

Perkembangan teknologi dan informasi mengalami perkembangan yang sangat pesat, ditandai dengan perkembangan internet. Karena kebutuhan teknologi dan informasi yang sangat tinggi disegala bidang pekejaan salah satunya pendidikan juga perlu dievaluasi dengan pemanfaatan Teknologi Informasi dan Komunikasi untuk menunjang kegiatan operasional. Menurut (Alpusari, 2014) menyimpulkan bahwa, "Evaluasi adalah suatu proses merencanakan, memperoleh dan menyediakan informasi yang sangat penting untuk membuat alternatif keputusan". Informasi haruslah data yang sesuai dan mendukung perencanaan untuk tercapainya suatu tujuan.

Pendidikan yang berkualitas memiliki prospek kedepan yang lebih baik dari,sebelumnya, namun untuk merealisasikan hal tersebut dibutuhkan evaluasi yang matang agar dapat menunjang terciptanya pendidikan yang berkualitas. Menurut (Astrini \& Melly, 2016) menyimpulkan bahwa : Kualitas pendidikan dipengaruhi oleh tiga hal yaitu tujuan, proses dan hasil pembelajaran. Tujuan pembelajaran mengarahkan proses pembelajaran yang akan dilakukan oleh pendidik. Proses pembelajaran dilakukan berdasarkan pada tujuan yang telah ditetapkan. Proses pembelajaran terjadi 
jika terdapat interaksi antara pendidik dan peserta didik. Hal ini erat kaitannya dengan sumber belajar yang diperlukan untuk melaksanakan proses pembelajaran. Sumber belajar berupa guru, buku, dan lingkungan sehingga tingkat kompetensi yang dicapai peserta didik menjadi tujuan akhir dalam melaksanakan proses pembelajaran.

Sistem informasi berbasis web sudah banyak diterapkan diberbagai sekolah. Informasi yang ditayangkan melalui website telah memberikan banyak pilihan dan manfaat yang dibutuhkan guru dan siswa untuk mengetahui berbagai layanan informasi yang ada di sekolah secara online dan offline.

Kesulitan para guru dalam hal mendapatkan soal dengan periode tahun yang berbeda yang akan diberikan kepada siswanya merupakan sebuah kendala. Masuknya internet ke sekolah-sekolah merupakan sarana menguntungkan bagi guru untuk memberikan soal dan penilaian, sedangkan siswa dapat memperoleh soal dengan mudah cukup dengan terhubung ke internet.

Dengan adanya sistem penyajian Bank Soal, guru dapat memberikan penilaian yang baik dan terencana sehingga dapat menunjang keberhasilan proses pembelajaran. Selain itu siswa juga dapat mengakses soal dimanapun dan kapanpun tanpa harus hadir disekolah. Selain itu siswa juga dapat mendownload materi file dan mengupload tugas berdasarkan jenisnya untuk dipelajari dan diterapkan dalam kehidupan sehari-hari. Penilaian dapat dijadikan pedoman untuk mengambil proses pembelajaran kedepannya.

\section{METODE PENELITIAN}

Teknik pengumpulan data dan sistem adalah serangkaian kegiatan atau cara untuk mendapatkan data atau informasi dari objek yang diteliti, beberapa metode penelitian yang penulis gunakan sebagai berikut:

\section{a. Observasi}

Selama riset penulis melakukan pengamatan langsung terhadap kegiatan-kegiatan yang berlangsung di sekolah sehingga mendapatkan data dan informasi mengenai sistem informasi akademik yang sedang berjalan.

b. Wawancara

Penulis melakukan kegiatan tanya jawab secara langsung dengan Kepala Sekolah yaitu Bapak Priyo Nur Cahyo, S.E., M.M., Staff Kurikulum yaitu Bapak Muhajar, S.Pd. dan Wali kelas yaitu Ibu Sri Hastuti, S.Pd.

\section{c. Studi Pustaka}

Dengan metode studi pustaka ini, penulis mendapat sumber data dari buku-buku dan jurnal yang berhubungan dengan studi literature pada buku atau referensi yang berkaitan dengan perancangan sistem bank soal.

d. Analisa Kebutuhan

Berdasarkan hasil analisis permasalahan mengenai sistem penyajian bank soal sangat diharapkan sebuah sistem yang terkomputerisasi dan dapat mengatasi masalah dalam proses kinerja pihak terkait. Sistem yang dibangun terdiri dari 3 pengguna sistem yaitu:administrasi, guru dan siswa.

e. Desain

Sistem informasi penyajian bank soal berbasis web (internet) dibangun menggunakan bahasa pemrograman PHP serta database MysQL dan desain sistem dibuat menggunakan UML (Use case Diagram, Activity Diagram, Component Diagram, dan Deployment Diagram). Program ini berisi sub sistem mulai dari pengolahan data siswa, data kelas, latihan soal, data mata pelajaran, penyajian soal berdasarkan jenisnya serta informasi lainnya yang masih berhubungan dengan sistem penyajian bank soal.

f. Code Generation

Code Generation adalah melakukan penerapan hasil rancangan ke dalam bentuk yang dapat dibaca dan dimengerti oleh komputer.

g. Testing

Dalam skripsi ini metode testing atau pengujian yang dilakukan adalah Black Box Testing. Black Box Testing adalah metode uji coba yang memfokuskan pada keperluan software.

h. Support

Support adalah kegiatan pemeliharaan terhadap data-data yang ada didalam sistem dan dilakukan secara rutin.

\section{HASIL DAN PEMBAHASAN}

Sistem penyajian bank soal berbasis web merupakan sistem yang berjalan secra online dimana siswa dapat melakukan download, upload dan mengerjakan tugas yang dibuat oleh pengajar. Soal tersebut akan dipantau oleh admin yang nantinya siswa tidak bertatap muka secara langsung dengan pengajar. 


\section{Use Case Diagram Halaman Admin}

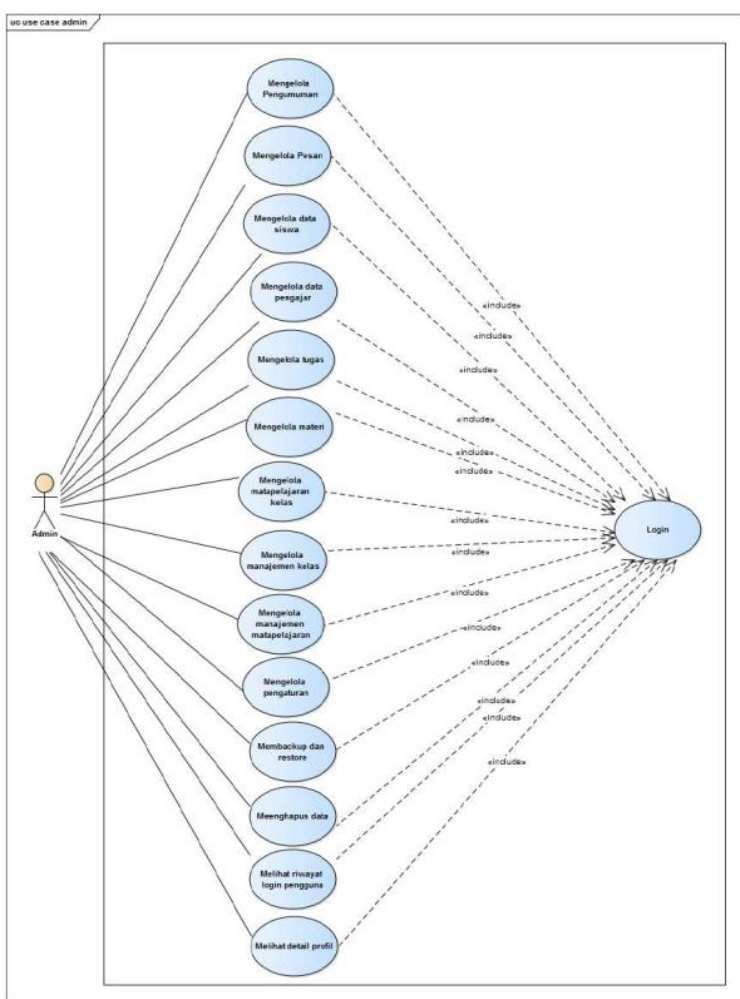

Sumber: Dokumen pribadi penulis 2019

Gambar 1: Use Case Diagram Halaman Admin

\section{Use Case Diagram Halaman Pengajar}

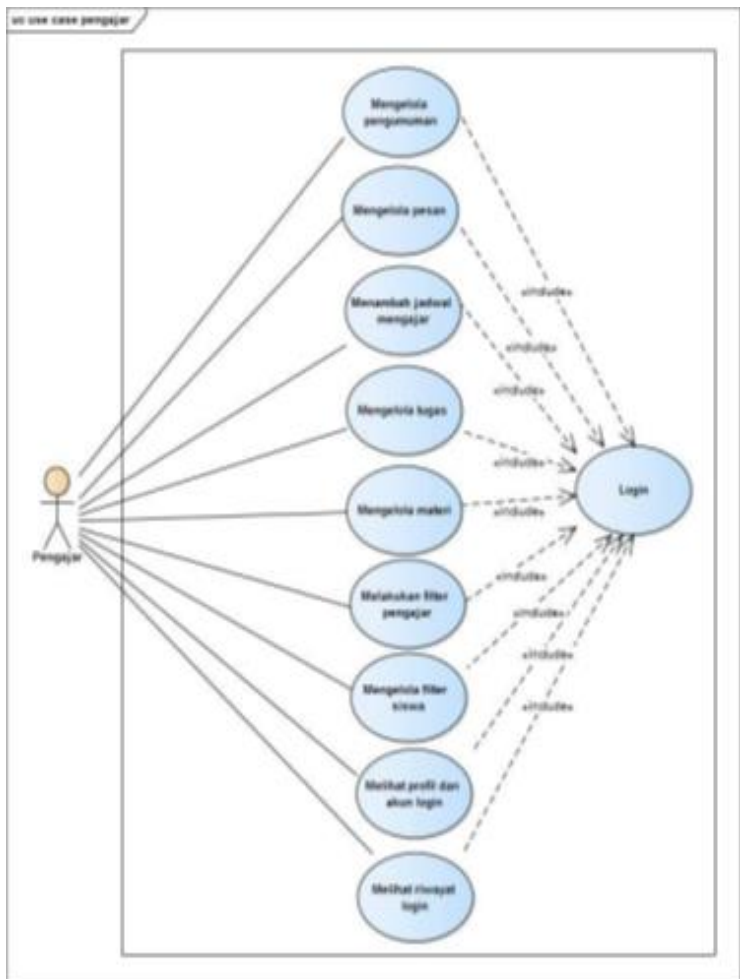

Sumber: Dokumen Pribadi Penulis 2019

Gambar 2: Use Case Diagram Halaman Pengajar
3. Use Case Diagram Halaman Siswa

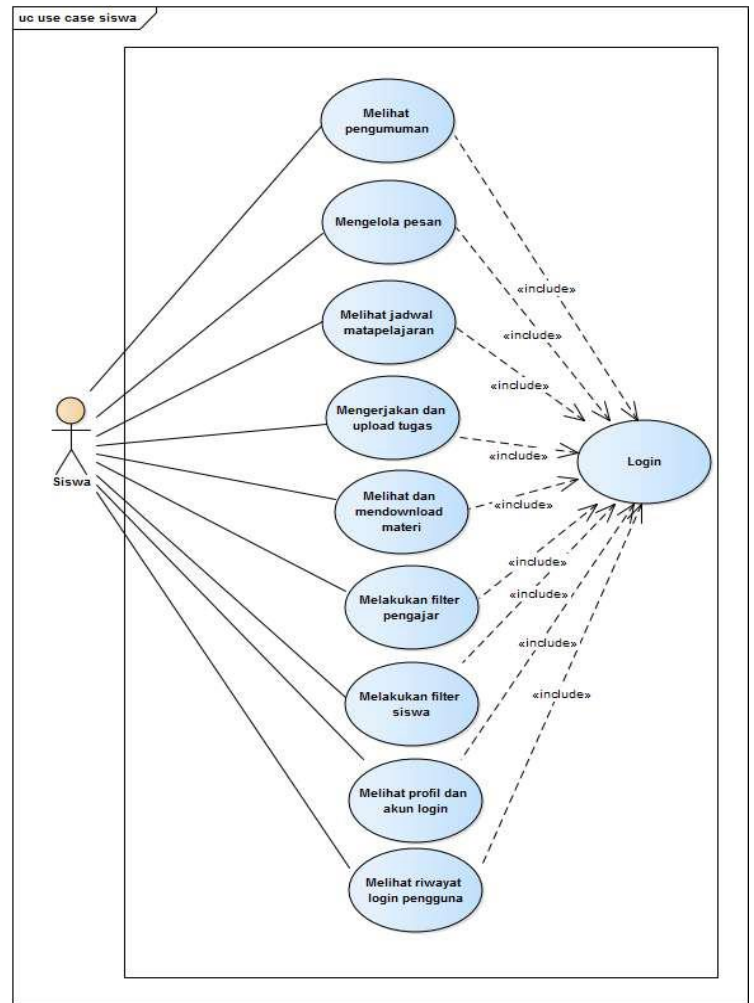

Sumber: Dokumen Pribadi Penulis 2019

Gambar 3: Use Case Diagram Halaman Siswa

4. User Interface

a. Halaman Login User

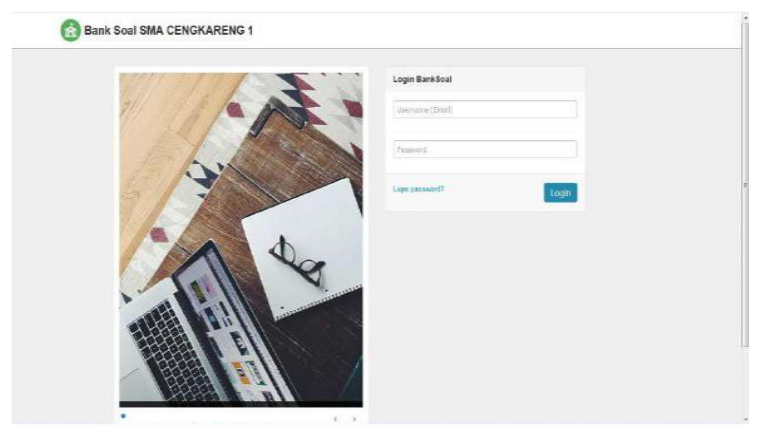

Sumber: Dokumen pribadi penulis 2019

Gambar 4: Tampilan Halaman Login User

b. Halaman Utama Admin

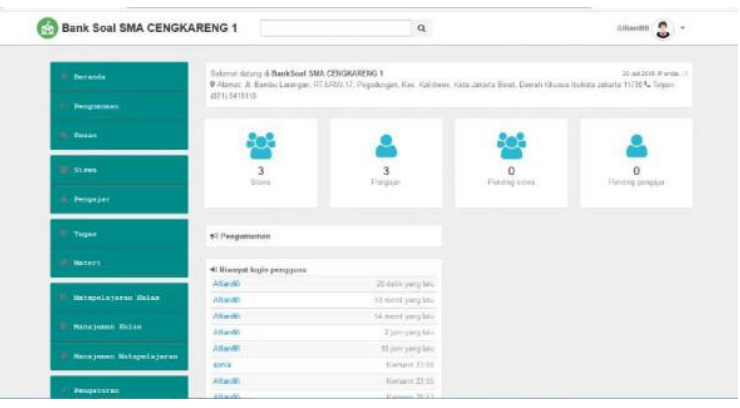

Sumber: Dokumen pribadi penulis 2019

Gambar 5: Tampilan Halaman Utama Admin 
c. Halaman Admin Menu Pengumuman

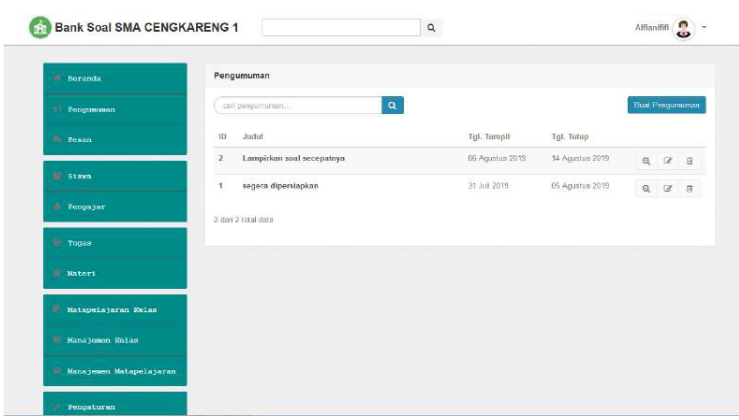

Sumber: Dokumen pribadi penulis 2019

Gambar 6: Tampilan Halaman Admin Menu Pengumuman

d. Halaman Admin Menulis Pesan

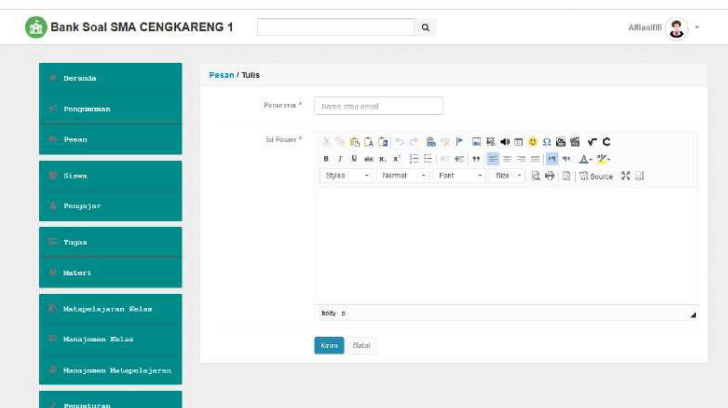

Sumber: Dokumen pribadi penulis 2019

Gambar 7: Tampilan Halaman Admin Menulis Pesan

e. Halaman Admin Menambah Siswa

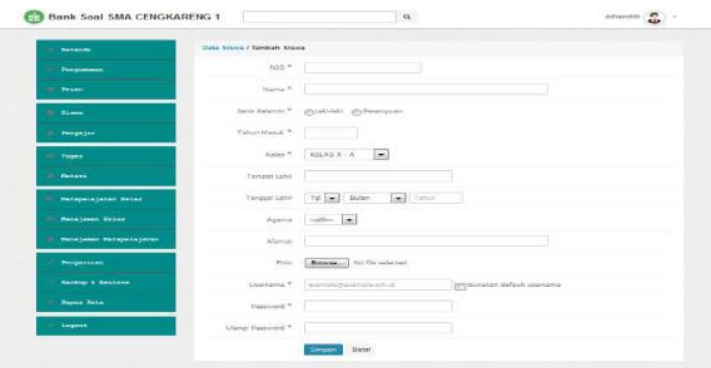

Sumber: Dokumen pribadi penulis 2019

Gambar 8: Tampilan Admin Menambah Siswa

f. Halaman Admin Menambah Pengajar

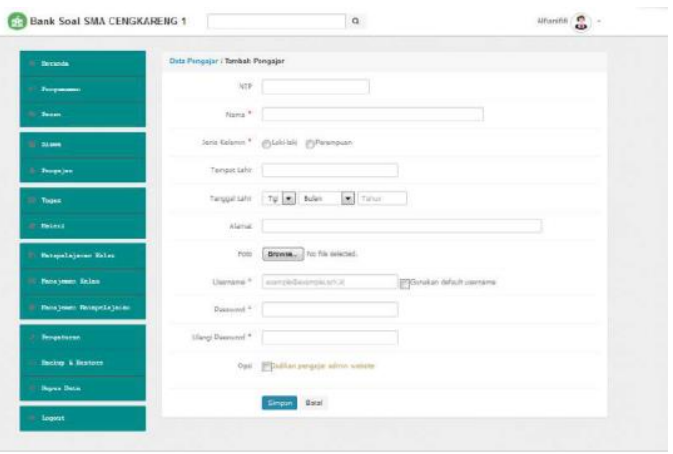

Sumber: Dokumen pribadi penulis 2019

Gambar 9: Tampilan Halaman Admin Menambah Pengajar g. Halaman Admin Menambah Tugas

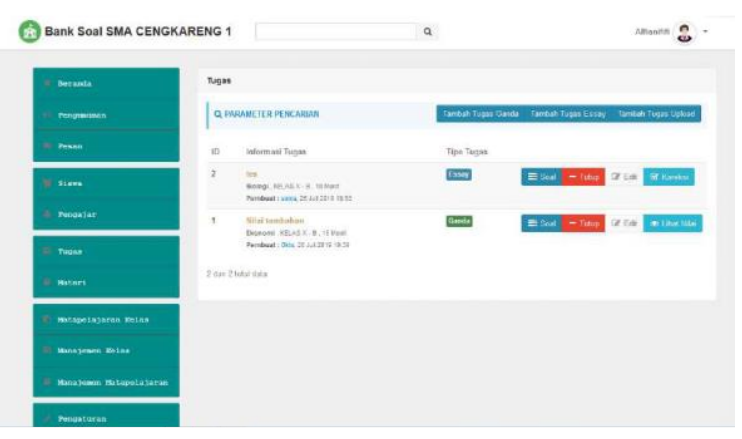

Sumber: Dokumen pribadi penulis 2019

Gambar 10: Tampilan Halaman Admin

h. Halaman Admin Menu Materi

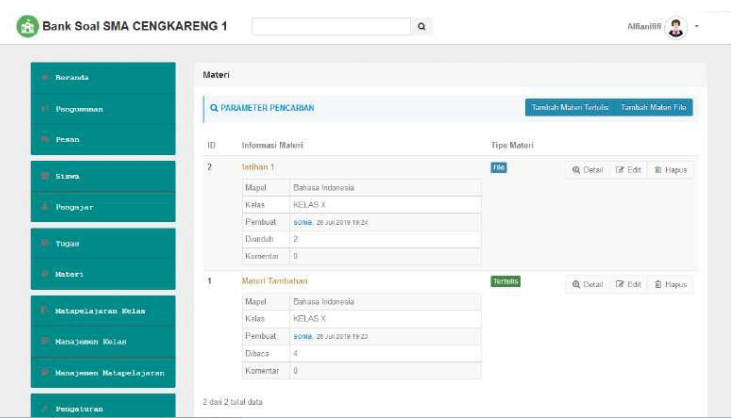

Sumber: Dokumen pribadi penulis 2019

Gambar 11: Tampilan Halaman Menu Materi

i. Halaman Admin Menu Matapelajaran

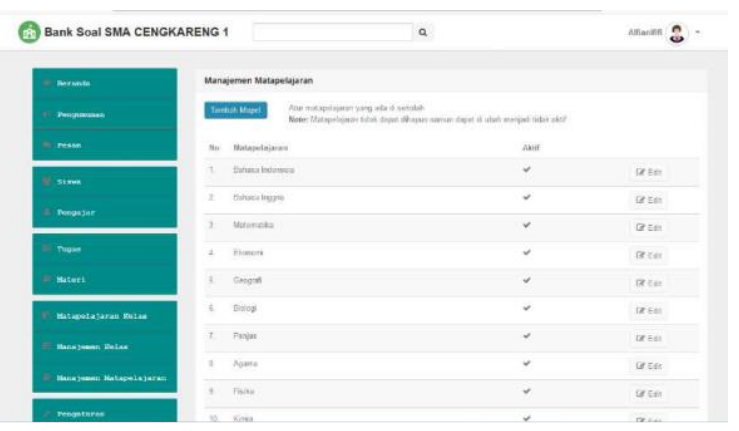

Sumber: Dokumen pribadi penulis 2019

Gambar 12: Tampilan Menu Matapelajaran

j. Halaman Admin Menu Pengaturan

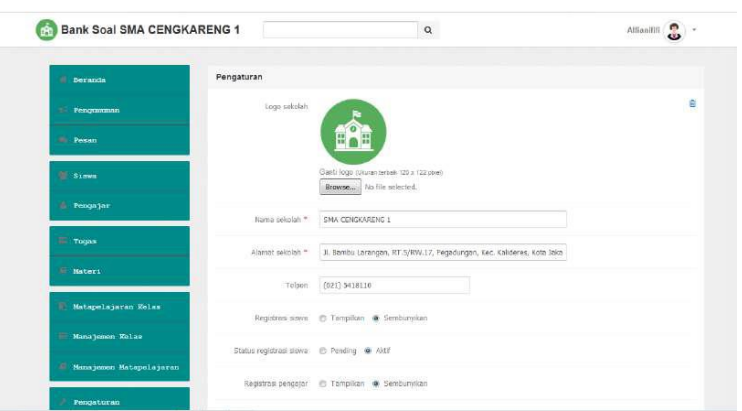

Sumber: Dokumen pribadi penulis 2019

Gambar 13: Tampilan Menu Pengaturan 
k. Halaman Profil

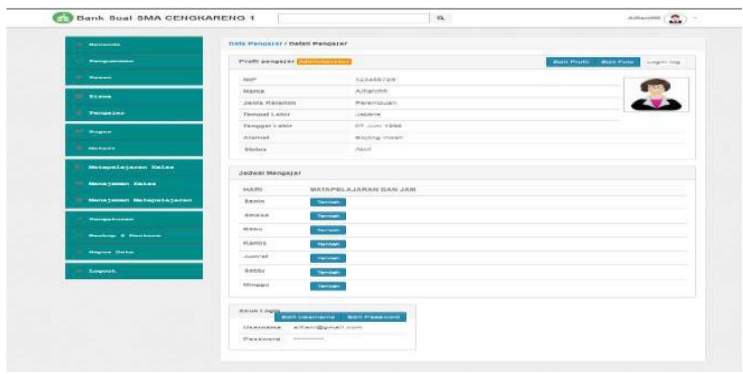

Sumber: Dokumen pribadi penulis 2019

Gambar 14: Tampilan Halaman Profil

1. Halaman Admin Hapus Data

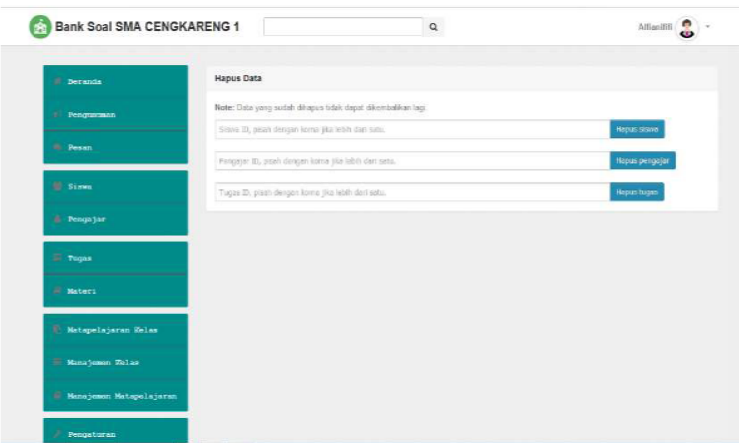

Sumber: Dokumen pribadi penulis 2019

Gambar 15: Tampilan Halaman Hapus Data

m. Halaman Utama Siswa

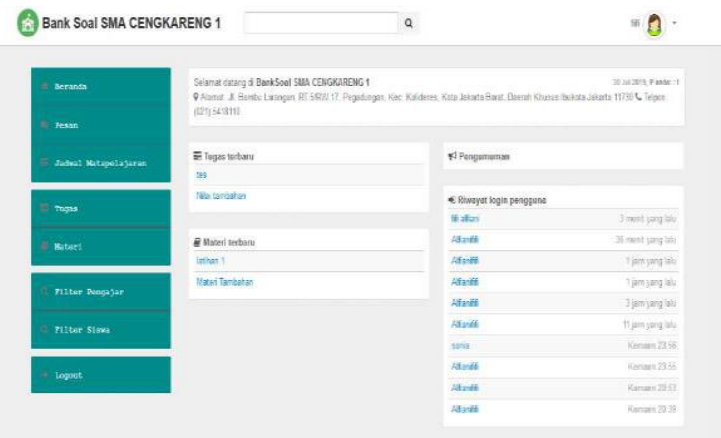

Sumber: Dokumen pribadi penulis 2019

Gambar 16: Tampilan Halaman Utama Siswa

n. Halaman Siswa Download Materi File

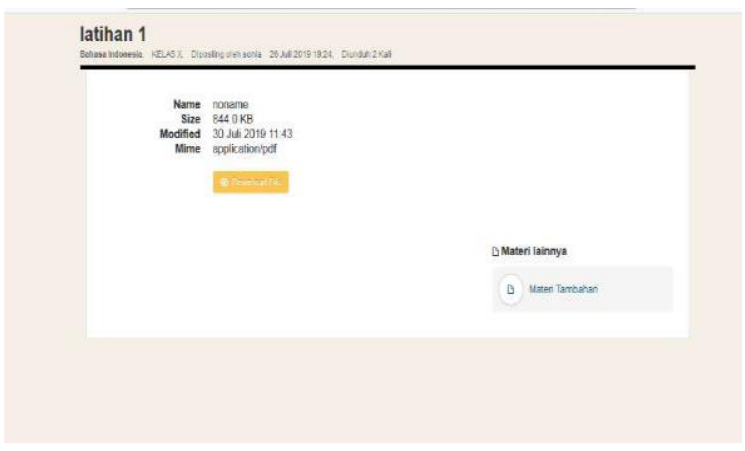

Sumber: Dokumen pribadi penulis 2019

Gambar 17: Tampilan Halaman Siswa Download Materi o. Halaman Nilai Siswa

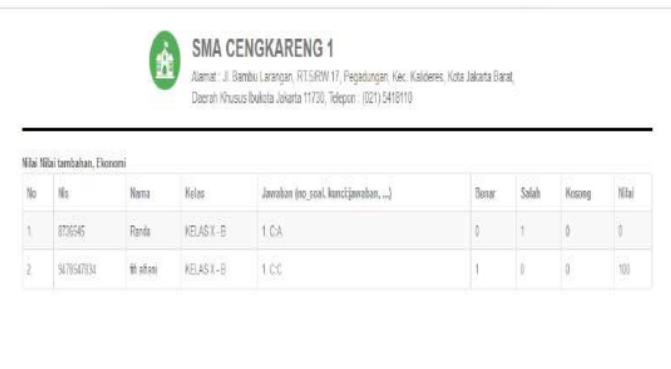

Sumber: Dokumen pribadi penulis 2019

Gambar 18: Tampilan Halaman Nilai Siswa

\section{KESIMPULAN}

Berdasarkan penelitian yang telah dilakukan oleh penulis di bab sebelumnya, penulis dapat memberikan kesimpulan yaitu sebagai berikut:

1. SMA Cengkareng 1 belum mempunyai Bank Soal yang berbasis web dan masih bersifat konvensional.

2. Menggunakan metode penelitian waterfall karena lebih sistematis dan urut dari level kebutuhan sistem.

3. Sistem penyajian bank soal jenjang sekolah menengah atas berbasis web memberikan kemudahan bagi pihak guru dan siswa dalam proses pembelajaran secara modern.

\section{REFERENSI}

Alpusari, M. (2014). Analisis Butir Soal, Program Komputer Anates Versi 4.0 For Windows Mahmud Alpusari. Jurnal Primary Program Studi Pendidikan Guru Sekolah Dasar Universitas Riau, 3(2), 106-115.

Astrini, D., \& Melly, A. (2016). Model Bank Soal Berbasis Web Untuk Menignkatkan Kualitas Pendidikan di Era Masyarakat Ekonomi Asean. Kimia Dan Pendidikan Kimia (JKPK), 1(3), 194-202.

Firman, A., Wowor, H. F., Najoan, X., Teknik, J., Fakultas, E., \& Unsrat, T. (2016). Sistem Informasi Perpustakaan Online Berbasis Web. Jurnal Teknik Elektro Dan Komputer, 5(2), 29-36. https://doi.org/10.35793/jtek.5.2.2016.11657

Habiby, A. I., \& Yamasari, Y. (2017). Sistem Informasi Sekolah Berbasis Web (Studi Kasus: TK Kusuma Putra Kota Mojokerto). Jurnal Manajemen Informatika, 7(2), 94-100.

Harison, \& Syarif, A. (2016). Sistem Informasi Geografis Sarana Pada Kabupaten Pasaman Barat. Jurnal TEKNOIF, 4(2), 40-50.

Hastanti, R. P., Purnama, B. E., \& Wardati, I. U. (2015). Sistem Penjualan Berbasis Web (ECommerce) Pada Tata Distro Kabupaten 
Pacitan. Jurnal Bianglala Informatika, 3(2), 1-9. https://doi.org/10.1007/s13226-018-0284-

Hutanaen, J. (2015). Konsep Sistem Informasi. In Jurnal Administrasi Pendidikan UPI (Vol. 3, Issue 1).

Ma'rifati, I. S. (2015). Sistem Informasi Akuntansi

Pendapatan Sumbangan Pembinaan

Pendidikan (SPP) Pada SMU XYZ. Evolusi, 3(2), 1-4. https://doi.org/10.2311/evo.v3i2.212

Mulyadi. (2015). Analisis Dan Perancangan Bank Soal ( Studi Kasus: Sekolah Tinggi Ilmu Komputer Dinamika Bangsa ). Jurnal Ilmiah Media SISFO, 9(1), 248-259. http://ejournal.stikom-

db.ac.id/index.php/mediasisfo/article/view/165

Nursahid, Kusuma Riasti, B., \& Eka Purnama, B. (2015). Pembangunan Sistem Informasi Penilaian Hasil Belajar Siswa Sekolah Menengah Atas (SMA) Negeri 2 Rembang Berbasis Web. IJNS-Indonesian Journal on Networking and Security, 4(2), 54.

Prayitno, A., \& Safitri, Y. (2015). Pemanfaatan Sistem Informasi Perpustakaan Digital Berbasis Website Untuk Para Penulis. Indonesian Journal on Software Engineering, 1(1), 1-10. https://doi.org/10.4028/www.scientific.net/A MR.756-759.138 